\title{
Study on the Cultivation and Practice of Socialist Core Values of College Students
}

\author{
Chunfu Yang ${ }^{1}$, Dongliang Yang ${ }^{2 b}$ and Weihong Min $^{3 \mathrm{c}^{*}}$ \\ ${ }^{1}$ College of Animal Science and Technology, Jilin Agricultural University, Changchun 130118, China \\ ${ }^{2}$ College of Information and Technology, Jilin Agricultural University,Changchun 130118,China \\ ${ }^{3}$ College of Food Science and Engineering, Jilin Agricultural University, Changchun 130118, China \\ àangchunfu197242@163.com, ${ }^{b} 610557217 @ q q . c o m,{ }^{C} 65817713 @ q q . c o m$
}

*The corresponding author

Keywords: Cultivation; Practice; Socialist core values; Problems; Implementation path

\begin{abstract}
It is imperative to cultivate and practice the socialist core values of College students. Colleges and universities should make the work effective by the theoretical guidance, institutional guarantee, educational innovation and optimization of the environment.
\end{abstract}

\section{Introduction}

The socialist core values are highly concise and incisive summary of the socialist core value system is also the general requirements of the whole Party and the people of all ethnic groups and the code of conduct. General Secretary Xi to cultivate and practice the socialist core values has advanced to the soul of condensate gas gathering, consolidating the height. [1] How to feed college students with the core values of socialism, so that they become a creative talent in line with the requirements of the times as soon as possible to become an extraordinary education project which must be done well.

\section{It Is Imperative to Cultivate and Practice the Socialist Core Values of College Students}

The Connotation of Socialist Core Values. Socialist core value is the core of the socialist core value system, and runs through all aspects of the basic content of the socialist core value system. The report of the Eighteenth National Congress of the CPC uses 24 words to summarize the socialist core values: "advocate a prosperous, democratic, civilized, harmonious, advocating freedom, equality, and justice, the rule of law, advocate patriotism, dedication, and integrity, friendly." Here from the state, society and individual three aspects are detailed, concise and comprehensive, broad and profound. We can say that it is a highly concise socialist core value system and concentrated expression. To promote the formation of the mainstream values of the country, gather the consensus and strength of the people of the whole country, ensure that the correct direction of socialism have a very important guiding significance and leading role.

The Significance of College Students to Cultivate and Practice the Socialist Core Values. President Xi Jinping at Peking University, "Youth must consciously practice the socialist core values", pointed out in his speech that "youth is in the formation and establishment of values, and it is very important to pay attention to the formation of values in this period." mentors and ardent hope of President $\mathrm{Xi}$ is that because college students are the spirit of the national spirit and the times of the promotion and the undertaker, the formation of the core values of the nation's future prospects and destiny, but also related to their personal growth and development. At present, the mainstream values of college students in our country are positive, healthy and upward, however, there is also a part of College Students' ideological values and their great and glorious and arduous historical responsibility, which is far from the requirements to the party, the country and the people of their expectations. to this end, study the college student's the core values of the misunderstanding and give the correct guidance in learning, life, to enhance their sense of identity and responsibility for the core values of socialism which is a very urgent task for us.[2] 


\section{College Students to Cultivate and Practice the Socialist Core Values Face Problems}

The Deviation of Value Orientation. The Marx doctrine is the guiding ideology of our work, of course, also is the commander and the soul of the construction of colleges and universities. However, due to the deviation of value orientation of some teachers in Colleges and universities, the senses of responsibility is not strong, in the teaching practice, one-sided pursuit the academic and ignore the political; A considerable part of the students learning indifference, playing mobile phones, sleeping and other phenomena are not uncommon, thus, the understanding of Marx's socialist core values is superficial and utilitarianism prevails, so to firm dominant position of the firm Marx doctrine in the construction of colleges and universities and to cultivate and practice the core values of socialism is an urgent task for the ideological construction in Colleges and universities.[3]

The Lack of Rational Thinking. Although some students have mastered the more profound knowledge, because some reasons for the basic viewpoint of Marxism, the basic position and the basic method of the master is not comprehensive and solid, it is not correct to use the theory of Marx doctrine to analyze, judge and solve all kinds of problems in the society. The views of a series of social problems, such as the relationship between the state and the nation, are biased and lack of rational thinking, Some even help the society some abnormal phenomena in flames, evil.[4]

The Infiltration of Bad Thoughts in the West. College students are willing to accept new things, strong curiosity, however, the hidden penetration of western social thought is often lack of ability to identify and recognize, but just with blind faith and following. The decadent ideology and culture of the western society further disturb the thought of college students at the forefront of culture, have a negative effect on the way of life and behavior, the value orientation of college students and even the spirit of "identity", which makes students have utilitarian and other bad ideas in life, learning and communication, ideological transition, transition behavior of indulgence.[5]

The Influence of Social Negative Phenomena. College students are in the formative period of values, which are easily affected by fluctuations, the rules of the mighty king of utilitarianism and the first competition crazy erode people's soul with money worship, hedonism,; The understanding error of unfair distribution and inequality between the rich and the poor, such negative information will make the formation of the socialist core values of the university is difficult to work.[6]

Moral Standard Fuzzy. In the modern society with diversified value orientation, and the moral standard of diverse, Some sensible and axiom were in question; Traditional morality is challenged, For example, whether the elderly fall on the road should be raised and young man to save the drowning man and dedication is worth it and so on whose answers are no doubt, but in the minds of some people draw a question mark, which must affect the formation of the socialist core values of College students.

\section{The Path to Cultivate and Practice the Socialist Core Values}

Theoretical Guidance, Clear Direction. Marx thought is the soul of the socialist core values and the highest level and determines the nature and direction of the socialist core values. The broad and profound Marx doctrine and the characteristics of the times decided that it is the leading thought of college students to establish a scientific world outlook, outlook on life and values. Universities must unswervingly adhere to the guiding position of the Marx doctrine, to understand, analyze and solve the problem correctly with the standpoint, viewpoint and method of Marx doctrine, effectively leading and integrating the social trend of thought, to ensure the construction of the campus along the right direction.

Sound Mechanism, System Guarantee. Colleges and universities should take cultivating the core values of college students in an important agenda, with direction clear, specific tasks, planning reasonable, the responsibility to the people to make the cultivation of college students socialist core values system with Institutionalization and normalization, and combine with the actual situation of schools and students, to develop, modify and improve college students' behavior norms, leading college students to establish the socialist core values.[7] 
Innovative Teaching to Get Recognition. The socialist core values are not only the guiding ideology of Ideological and political education of college students, but also the important content of Ideological and political education of college students, therefore, to cultivate the socialist core values of college students, first of all, the socialist core values should be included in the ideological and political course of the main teaching content, so that students understand the content, value.[4] Teachers should learn to optimize the content of teaching materials, combine the teaching content with the social facts, as far as possible to take some of the latest hottest, most realistic content into the teaching, with classroom discussion, case analysis, image projection etc. inspire students to think, to guide them to feel a sense of national pride, sense of honor and mission, so as to deepen their understanding of the connotation of socialist core value.[8]

Pay Attention to Practice, Cultivate Ability. In the process of cultivating students' values, it is very important to combine the values of the classroom with the values of education. Practice is the basis of the core values of the generation and development and all genuine knowledge comes from practice, which let the positive energy of the community to nurture, infect and modify the values of the initial formation of students, making practice of educational activities become the motivation of College Students' learning and Practicing Socialist Core Values inexhaustible.[9]

Create Atmosphere, Optimize Environment. Strong education atmosphere and a good environment are the important factor to cultivate and practice the socialist core values, and the campus culture is the focus of the spiritual outlook, value tradition and humanistic environment, which is an important part of the extension, supplement and general teaching activities of college classroom teaching, and has irreplaceable function in cultivating and practicing the socialist core values. First of all, the school through a series of effective measures form a good school spirit, teaching style and learning style; Secondly, a series of activities should be carried out in combination with the school to purify the campus and optimize the environment; what's more, to Establish the linkage mechanism of school, family and society three, the influence of family on students' core values is subtle, but also more specific, so the school should actively strengthen the contact with parents, take the initiative to support local government departments, Through a variety of ways to encourage students to society and serving the society, let them feel the warmth of the society and charm in social practice activities, to form a good habit of self-discipline, self-correction and active participation.[10]

\section{Summary}

In short, college student to cultivate and practice the socialist core values is the inevitable trend of the construction of colleges and universities must cause enough attention. Colleges and universities should highlight the leading role of the socialist core values, and actively carry out a series of activities with patriotism as the center, to create a good atmosphere of education, to cultivate the characteristics of the times very fruitful to more creative talents.

\section{References}

[1] J.P. Xi: Young people should learn to practice the socialist core values -- Peking University teachers and students in the forum speech [EB/OL]. Xinhua News Network on http://xuan.news.cn, 2014-05-05. (In Chinese)

[2] W. Liu:Integrate the socialist core values into the ideological and political education of college students [J]. Education Science, 2014 (3); 73(In Chinese)

[3] Z. Li:Think the path of Cultivating College Students' socialist core values [J].Journal of Yunnan Agricultural University, 2014 (1): 49-54. (In Chinese)

[4] R. Ou:The survey of college students to cultivate and practice the socialist core values -- a case study of Guangxi College [J]. Chinese school education management for publication, 2014 (27). (In Chinese) 
[5] X. Yuan, A.H. Wang:College students socialist core values education path [J]. Ideological and Political Education Research, 2013 (16). (In Chinese)

[6] F.N. Ren, Y. Qin:The guidance and cultivation of College Students' socialist core values under the mass media environment [J]. Journal of Xi'an Jiao Tong University (SOCIAL SCIENCE EDITION), 2014 (3). (In Chinese)

[7] Z.H.Fang:How to cope with the change of the value orientation of college students in universities and colleges [J].Journal of Jimei University (SOCIAL SCIENCES), 2004 (I) (In Chinese)

[8] Y.P. Liu: Discuss the building of college students' socialist core values of three dimensions (In Chinese)

[9] X.J. Wang,D.P. Li: The study of socialist core values [J]. Ideological and Political Education Research, 2013 (4). (In Chinese)

[10] Y.G. Wang: The socialist core values cultivating targets and paths [J]. Ideological and theoretical education, 2013(3). (In Chinese) 